\title{
Reviving the Almajiri Integrated Model Schools in Northern Nigeria: A Pathway to Countering Terrorism
}

\author{
Okadigwe, Nkechi Mary Ph.D. \\ Department of Theatre and Film Studies, Nnamdi Azikiwe University, Awka, Nigeria \\ Akas,Nicholas Chielotam Ph.D. \\ Department of Theatre and Film Studies, Nnamdi Azikiwe University, Awka, Nigeria
}

\begin{abstract}
Boko Haram, the Islamic terrorist group who predominantly has its base in North East Nigeria appears to draws some of its recruits from the Almajiri, the wandering Islamic pupils. This appears to have escalated the number of teenagers within the terrorist group making it a matter of high concern that needs to be addressed. Although, the federal government has taken lots of measure to counter terrorism in Nigeria, most of these measures appear to be on reactive measures such as military responses. Since most of the teenagers who join Boko Haram appear to do so due to ideological extremism, it becomes imperative to include soft power such as quality formal education to moderate religious prejudices that trigger hate for individuals who are religiously and culturally different. This research therefore recommends that government should include the use of soft power such as education in its fight against terrorism. The already instituted Almajiri integrated modern schools should be revived and boosted with incentives and modern educational facilities. Government's concentration in modernizing Almajiris' education and rehabilitating the already radicalized will go a long way to address the drivers of terrorism which is usually born by religious extremism and intolerance for others. It is hoped the target will eventually be built with confidence and understanding to resist hateful propaganda that legitimate the use of violence. The researchers used changed theory for this study.
\end{abstract}

Keywords: Boko Haram, Almajiri, Formal education, Terrorism, Northern Nigeria, ideological extremism, Religious prejudices, incentives, federal Government.

DOI: $10.7176 /$ RHSS/9-1-01

\section{Background}

The growing number of teenagers joining Boko Haram in Northern Nigeria has become a matter of high concern that calls for urgent attention. Boko haram 's act of using explosives in mass destruction of lives and properties makes the group a national threat. Over the years, the group has continued to unleash its deadly attacks on innocent civilians mainly in North-East Nigeria. Unfortunately, the group has variously used teenagers to carry out violent attacks on lives and properties. Although government has employed various means to help curb the activities of the deadly group, the group has continued to wax stronger. Government's effort to capture the leaders of the group seems to have proved abortive. Instead of government's efforts scaring potential terrorist and preventing them from joining the group, more teenagers are found to join in perpetrating the group's inhumane attacks. It thus appears that there is an underlying power motivating teenagers towards violence. Religious radicalization, circumscribed and prejudice religious teachings, despondency, pre-exposure to violence in Almajiri schools and ignorance appear to be huge contributors to the continued outgrowth of Boko Haram terrorism.

The harsh tutoring mode, street begging tradition, hopelessness for a promising future and ignorance seem to join to nurture the Almajiri pupils into violent individuals who perceive other individuals of diverse religion and ethnicities with hate and antagonism. Drawing analogy of similar educational systems in Central Asia prior to , during, and following Russian communist rule, Awofeso, Jan, Ritchie, Jan and Degeling, Pieter aver this about the Almajiri in Northern Nigeria:

Given the lessons from the 1980 Maitatsine terrorist insurgence in kano, Nigeria, and the rise of Islamic fundamentalism in Northern Nigeria since 1999, a potential exists that the heritage may evolve into an apparatus for perpetuating non-state terrorism.

The Almajiri schools thus appear to be grounds for the breeding of potential terrorist. The Almajiri Islamic schools structure usually consist of male children from poor homes, Mallam (Islamic teacher) and his assistant. The parents of these children literarily dump them in the boarding schools under the care and supervision of Mallam, the Islamic teacher who in turn sends them out to beg for arms. Narrating the emergence of Almajiri in Northern Nigeria, Abdulqadir reports that when the British colonial masters colonized Northern Nigeria, they abolished the state funding of Almajiri schools. The Mallams were thus left with the lone burden of catering for the pupils financially and otherwise. This development prompted the Mallam to send his pupils out to beg for arms on the streets. They are often seen in the streets singing and begging for money and food.

Online Editor in This Day relates that: 
Originally, the almajiris were male pupils of school age who left home in search of Qur'anic education. They were placed in care of teachers who would prepare them for learning the basics of Qur'anic education. But the teachers, in most cases, were unable to meet all the needs of their pupils. The students were therefore obliged to beg in the neighbourhood to supplement their rations and other needs.

The begging tradition of the Almajiri pupils thus set them out of their Mallam's supervision at the time they are out to beg. This tradition appears to expose the Almajiris to individuals who influence them negatively. The Almajiris are thus given to negative habits that culminate from their free and easy contact with individuals who are morally depraved such as prostitutes, hoodlums and terrorists. Almajiri thus appear malleable to abuse, drugs and various forms of manipulation. Their wandering nature makes them easily accessible to terrorists such as Boko Haram. These Almajiri teenagers appear to be radicalized with extreme religious ideology. So Almajiri being encapsulated with prejudiced religious teaching tends to be the most vulnerable to religious terrorist sects such as Boko Haram.

\section{Islamic Ideology on Almajiri Children}

The rhetoric question that comes on one's mind is whether an Almajiri ideology is for both the rich and the poor . The answer can either be answer Yes or No based on superior argument. But in this paper, the researchers choose to say yes, that Almajiri ideology seems to be meant for the poor children only based on the available observation. The harsh Islamic ideology on the Almajiri system of livng is a dehumanizing tool on the wellbeing of the children who are trained at times on myopic understanding and belief in being foot soldiers, human robots and destructive agents. This bastardized ideology associated with them makes the Almajiri children be rejected by the society which they are suppose to be working for especially non-Islamic. In the Islamic belief or religious system they are accepted as slaves, beggars and wanderers who depend only on Almighty Allah for their survival only. Abdulazees Balogun Shitter reacted by saying:

Islamic ideology discourages the believers from condemning themselves to the low ebb of affairs right from the onset. Rather one has to do everything to aim high and work towards not achieving his goals except Allah's decisions. (41)

So this ideology has left the Almajiri children on two crossroads of thoughts: either to be or not to be. But not to be acceptable among their mates in Nigeria has subjected the Almajiri children to modernized slavery denying them western education, exposure and logical reasoning. This paper therefore states subjectively as it progresses that the harsh Islamic ideology placed on Almajiri children should and must be corrected towards achieving the intended counter terrorism especially in Northern part of this country.

\section{Theoretical Framework}

The hopeless state of Almajiris on the street of Nigeria especially in the North is a big eye-sore on societal psyche of concerned citizens. Some people without religious sentiment are no longer happy watching the Almajiri children wander aimlessly as if they don't have any future or families to hold on to. Some of them their parents, though religious, but are not happy anymore giving out their children to Mallam.

One can also ask, is the Almajiri system of education meant for the children of very poor families or is it applicable to the children of the rich people? But base on close observation and experience, the researchers humbly took a stand that it is solely meant for the poor children from very poor homes. The rich desire their children to learn Islamic religious system, but not to wander on the streets, as beggars or used as terrorists attack nor believe that they are doing it for Almighty Allah. What they do is to send their children to the best schools outside the country to be refined, exposed and taught in a much better way to believe in Almighty Allah doctrine. Based on this, some of the parents of the Almajiri children undergo a lot of emotional, psychological and moral depression about the loss of basic education of their children like the children of the rich ones, not seeing their children because of their wandering habits due the Almajiri system of education and exposing their children to environmental challenges such as terrorism.

But based on counter terrorism and managing the traumatized situations of the parents or the Almajiri children themselves, this paper therefore adopted a working theory by Thompson J. Theory of Crisis Intervention.

This use of Crisis intervention Theory is very apt in this paper. The current critical situation of Nigeria, make some parents commit suicide in the Northern part of the country based on the defaced human situations of their children, and the Almajiri children commit murder or become suicide killers believing they are registering their name in the good books of Almighty Allah. In order to manage these ugly situations Thompson J. stated that "Crisis Intervention theory guides parents and society at large on how to respond positively and manage child right abuses with high level of rationality without death". (46).

He further stated that

Crisis intervention Theory helps give children sense of belonging in building a close relationship with their families in unforeseen situations and understand their roles to be change agent in shunning evil and accepting good. (48) 
With the above assertion, counter terrorism aimed to be achieved in this paper can be workable both for the parents, children and society at large through the use of crisis intervention theory as the theoretical framework.

\section{Dehumanization of Child Right in Almajiri}

The poor situations of Almajiri children in the Northern part of Nigeria especially those from poor families are very alarming, heartbreaking and dehumanizing. The Almajiris are supposed to be like every average Nigerian child, who should enjoy every required rights available to them, but the Almajiri children are different ugly ball game. They lack the basic amenities every growing child should have not because of survival of the fittest, but rather because of mandatory obligation of denial of education, sound parental care, good feeding, health and moral upbringing, culminating in debased lifestyles of street begging, terrorism, thieving, rape and wandering.

The act of denying Almajiri children their basic rights has really dehumanized their mental belief to see those basic amenities as thing for the unlucky ones or unbelievers, while those who want to follow and maintain the preaching and doctrine of Almighty Allah must always suffer and ready to do anything. Fafunwa as cited by Fowoyo Joseph stated that "A good Almajiri child is the one who learns Quran, suffers and the wants to teach it" (67). Trying to live the doctrine of the Islamic tradition is good, but not when it affects the well being of an Almajiri (child) and his rights.

The Almajiri children are supposed to be the future Islamic leaders or Imans of tomorrow based on Islamic teachings, but how can it be possible and achievable with the current situation of Almajiri children where they are denied the basic child rights and turn to deadly terrorists. Some who are not terrorists are exposed to deadly diseases cum acts such as Gayism, HIV/AIDs, Tuberculosis, Hepatitis B and other diseases, because of their reckless lifestyles. This paper advocates that Almajiris should be removed from the streets, resensitized and restored their lost basic child rights more especially returning them to classroom. But inability to achieve this, the psyche and thought of Almajiri children in Nigeria become the country's nightmare. Akas Nicholas suggested that

When a child lacks the basic necessary amenities at developmental stage and not well managed psychologically, morally and socially, that particular child becomes warfare for human destruction (72)

\section{Contributions in Reviving Almajiri Integrated School}

The situation of Almajiri children is a critical one before the Federal government of Nigeria. The masses are no longer happy with the conditions of the Almajiris especially when it comes to their education. Education is a basic need for every child so they don't need to be deprived of it. It is based on this that Musa Adeyemi Olaope suggested the following;

1. The key players in the education sector should key into the authority's intervention of giving the Almajiri children a second chance on education beyond the core area of Islamic learning

2. Government should provide more school for the Almajiri and resensitize them to value education and shun the myopic saying of "No to western education".

3. The Northern Governor's forum should properly scrutinize the activities of the mushrooming glorified Almajiri schools and make them to meet up to standard.

4. In order to revive Almajiri integrated schools, quality school should not be sacrificed on the altar of quantity at all levels of the nation's educational institution

While this research concurred with the above, it suggests that;

A. Community education should be made available at the door post of the Almajiri children who might afford modern schools.

B. Community Theatre for Development in collaboration with the government should dramatize topical issues before the children especially on the side effect of terrorism and how to avoid it.

C. The non-government organization should help to monitor Almajiri children standard of feeding and living because a child that feeds well understands well in the classroom. When all these are achieved and maintained, it will go a long way to countering terrorism, removing the children from the streets and returning them to their right place where they belong (classroom)

\section{Conclusion}

An average Almajiri child is really passing through hideous experience that needs both the Nigeria government and well to do citizens' attention. They should not always be written off as street children or terrorists; rather people should know that they can be anybody's children and start thinking on how to assist and pull them off the street and return them back to classroom. In order to achieve this, this paper advocates that people should strip themselves a little their selfish goals, desires and ambitions by caring for Almajiri children, especially their education, to make them feel loved, cherished and accepted against the wrong assumption of being rejected. Once this is achieved countering terrorism would have been achieved or terrorism minimized 


\section{Works Cited}

Abdula Zeez balogun Shittu \& Musa Adeyemi Olaife: Situations of The Almajiri System of Educational Contemporary Nigeria: Matters Arising, Ilorin Journal of Religious Studies. Vol. 5 no 2. pp 41-73. 2015

AbdulQadir I.A. "The Almajiri System of Education in Nigeria today" in

Akas Nicholas. Nigeria Music and The Bastardization of Cultural Norms in Child's Moral Development. A study of Flavours Musical Video If I Catch You, Nairobi Journal of Humanities and Social Sciences Vol. 2 (2) pp. 69-78. 2018

Awofeso, Niyi, Ritchie, Janand Degeling, Pieter. "The Almajiri Heritage and the Threat of Non-State Terrorism in northern Nigeria-Lessons from Central Asia and Pakistan" in Studies in Conflict and Terrorism. Vol. 26, Issue 4. https://www.tanfonline.com/doi/abs/10.1080/.2003

Fowoyo Joseph. Transforming The Almajiri Education for benefit of the Nigeria Society, Journal of educational and Social Research. Vol. 3 No 9. p43-65. 2013

Mac-leva, Fidelis, Umar, Shehu and Auwal, "N15 billion Almajiri Schools in Ruins" in Daily Trust. Saturday, June 30, 2018.Abubakar.https://www.dailytrust.com.ng/n15-billion-almajiri-schools-in-ruins.html

Okonkwo, Samuel O. "The Almajiri System and Violent Extremism in Northern Nigeria: Finding the Nexus" https://medium.com/@OS_Okonkwo/the-almajir-system-and-violent-extremism-in-northern-nigeriafinding-the-nexus-by-oge-samuel-aa

Online Editor. The Abandonment of Almajir Schools. In This Day. https.//hisdaylive.com/index.php/2017/12/22/the-abandonment-of-almajiri-schools/amp/

Thompson J. Crisis intervention Theory USA: University Press. 2017 